\title{
The seasonal and inter-annual patterns of biomass accumulation and crude protein in kleingrass (Panicum coloratum) in the semiarid Pampean region of Argentina
}

\author{
Carlos M. Ferri \\ Facultad de Agronomía. Universidad Nacional de La Pampa, CC 300 (L6300) Santa Rosa, La Pampa, Argentina.
}

\begin{abstract}
C. M. Ferri. 2011. The seasonal and inter-annual patterns of biomass accumulation and crude protein in kleingrass (Panicum coloratum) in the semiarid Pampean region of Argentina. Cien. Inv. Agr. 38(2):191-198. Kleingrass (Panicum coloratum L. var. coloratum) is a perennial warm-season grass that begins its growing season later in the spring than does weeping lovegrass (Eragrostis curvula (Schrad.) Nees), which suggests that combining weeping lovegrass with kleingrass in a grazing sequence could increase livestock production. The objectives of this study were to determine the seasonal and inter-annual variation of the patterns of the accumulation of dry matter (DM) and the percentage of crude protein (CP) in $P$. coloratum, cv. Verde, in the semiarid Pampean region of Argentina. This study was performed during four growing seasons in a 3.0 ha pasture of kleingrass that was sown in the spring of 1996. The forage samples were gathered at biweekly intervals and were separated into leaf blade, stems (including sheaths and inflorescence) and senescent material. Finally, patterns of dry matter accumulation and the percentage of crude protein were evaluated in relationship to the thermal time accumulated from early October to late February. In comparison with the other growing seasons evaluated, the third growing season had less $(\mathrm{P} \leq 0.01)$ accumulation of dry matter and a higher $(\mathrm{P} \leq 0.01)$ proportion of green leaf blade and $\mathrm{CP}$. Dry matter accumulation increased with increases in the thermal time. The $\mathrm{CP}$ percentage of the total biomass and of the plant parts declined as thermal time increased, and this coincided with a reduction in the proportion of green leaves and the CP percentage in each plant part. Management decisions depend on an accurate assessment of the change in sward structure and nutritive value during the growing season. The results of this study will allow selection of the appropriate grazing time and the management of sequential grazing of warm-season grasses.
\end{abstract}

Key words: Argentina, daily thermal variation, leaf blade, seasonal rainfall, semiarid Pampean region, total biomass.

\section{Introduction}

Complementary grazing systems (CGS) involve the rotation of animals between forage resources of species with different patterns of seasonal growth

Received November 21, 2009. Accepted January 31, 2011. Corresponding author: ferri@agro.unlpam.edu.ar and development (Gillen et al., 1999; Moore et al., 2004). The aim of the CGS is to overcome the seasonal deficiencies in the production of dry matter and nutrients content that are inherent to the use of a single resource. The advantages of CGS include more efficient use of each forage resource and the subsequent increase in animal carrying capacity (Gillen and Berg, 2001). 
The calden (Prosopis caldenia Burk.) forest extends over an elongated area in the temperate semi-arid Pampean region in central Argentina, which has a native gramineous stratum composed of cool-season grasses $\left(\mathrm{C}_{3}\right.$ species) and warm-season grasses $\left(\mathrm{C}_{4}\right.$ species), although, with a noticeable predominance of $\mathrm{C}_{3}$ species (Cano, 1980). In general, this forest clearly degraded by overgrazing and the exclusion of fire; this is, evident from the high density of Stipa species scrublands (SAyDS, 2006) that affects the animal carrying capacity. The degradation of the native vegetation determined the use of weeping lovegrass (Eragrostis curvula (Schrad) Nees), an exotic perennial warm-season grass, has been used as a pasture complement. Planting $15 \%$ weeping lovegrass in sectors free of woodland vegetation allowed a 33\% increase in the stocking rate and increased the number of weaned calves by $50 \%$ (Nazar Anchorena, 1988). This species begins to growing in the spring before the other exotic perennial warm-season grasses. It is highly nutritive at the beginning of the growth cycle but deficient during the summerfall period, when it reaches maturity and in the winter (Gargano et al., 2001), when it is used as standing deferred forage. The nutritional deficiency of weeping lovegrass during the summer-winter period fostered the search for an exotic $\mathrm{C}_{4}$ species adapted to similar environments as weeping lovegrass, but with maintenance of its nutritive value through the end of the growth season and preservation of it through the winter.

From the species studied, kleingrass (Panicum coloratum L.) is one of the species that has both high dry matter accumulation and high nutritive value. This species begins growing approximately four weeks after weeping lovegrass does, and it is known to have high forage accumulation (Stritzler et al., 1996) and nutritional quality (Ferri et al., 1998). Kleingrass began spreading in cattle systems 20 years ago (Petruzzi et al., 2003) because it is well adapted to the environment. However, in addition to selecting appropriate strategies for grazing management, it is necessary to know the seasonal changes in the accumulation and dry matter partitioning and the protein percentage of the different fractions of the plant.

The integration of the native pasture with weeping lovegrass and kleingrass, in a CGS would allow the combination of the highest production potential of weeping lovegrass during the early spring and the high nutritional value maintained by kleingrass until the end of the growing season. Additionally, the kleingrass growth accrued from late summer and fall could be used in winter as stockpiled forage due to its acceptable nutritive value (Ferri, 2002; Ferri et al., 2006).

The semiarid Pampean region in central Argentina is characterized by high interannual rain variability as the "El Niño/Southern Oscillation" phenomenon has a significant effect on climate throughout the Pampean region (Podestá et al., 1999; Yahdjian and Sala, 2008). The mean monthly rainfall from November to April is higher (lower) in El Niño years (La Niña) in comparison with normal years or with the long-term averages. The climate change forecast for the Southern Hemisphere is that temperature will increase and soil humidity will decrease in the next years (IPCC, 2007); thus, there is also a need for available alternative forage species that are adapted to these new conditions.

The goal of this study was to improve the CGS development for breeder herd sheep and/or bovines in the semiarid Central Pampean region within the wide seasonal and interannual climatic variability. The objectives included the identification of the seasonal and interannual patterns of dry matter (DM) accumulation and partitioning and the determination of the crude protein percentage $(\mathrm{CP})$ of kleingrass $(P$. coloratum var. coloratum, cv. Verde) for this region in relationship to the temperature (thermal sum) and the variability in rainfalls. The quantification of the biomass accumulation and the variation in the nutritive value for the different kleingrass plant fractions will allow the determination of the balances between quality and offer amount. This might allow the inclusion of kleingrass in the grazing sequence among the forage resources usually used in the region. 


\section{Materials and methods}

The study was conducted during four growing seasons (from 2001/02 until 2004/05) in a 3.0 ha kleingrass ( $P$. coloratum var. coloratum, cv. Verde) pasture sown in the spring of 1996 in a Haplustol entic soil in experimental field of the Faculty of Agronomy, Universidad Nacional de La Pampa (UNLPam), La Pampa, Argentina (36 46 'S; 64ำ $16^{\prime} \mathrm{W} ; 210 \mathrm{~m}$ asl). The soil was $2.34 \%$ organic matter and had $8.4 \mathrm{ppm}$ of extractable phosphorus (Bray-Kurtz) and a slightly acidic paste $\mathrm{pH}(6.3)$ in the surface horizon. The rainfall in the spring-summer period in the four growing seasons, varied between -40 and $+15 \%$ of the historic average rainfall (Figure 1); the spring-summer with the lowest rainfall (2003/04) followed a winter season with similarly low rainfall. The rainfall recorded during that winter was $25 \%$ of the historical average ( 22 vs. $92 \mathrm{~mm}$ ), whereas rainfall was higher than average during the other three winters (192, 204 and $121 \mathrm{~mm}$, in chronological order). The quantity of winter rainfall might determine the soil water status in the early growing season of the species being studied, which would affect the pasture productivity. The variability in the quantity and seasonal distribution of the rainfalls during the study allowed the evaluation of the effects of rainfall on the study variables among the growing seasons.

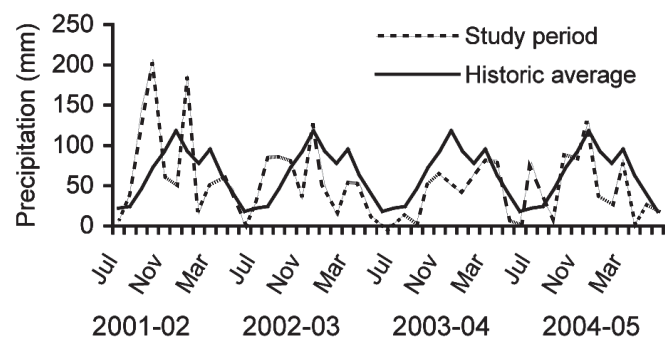

Figure 1. Rainfall in Santa Rosa, La Pampa, Argentina, during the study period. Dashed line denotes historic average (1975-2000).

The experiment was a complete randomized block design, with three repetitions and 10 harvest dates. Independent $1.3 \times 3.0 \mathrm{~m}$ plots were harvested at intervals of 2 weeks during a 140 days period, from the beginning of the growing season in early October until late February. For each harvest, the total biomass was cut at $2 \mathrm{~cm}$ above the soil level from all of the plants located within a $1-\mathrm{m}^{2}$ frame that was randomly placed on each plot. All of the samples were hand-separated into the leaf blade and stem fractions (S, including the leaf sheath and the inflorescence); then, the leaf blade fraction was separated into the green leaf blade (L) and the senescent material. The leaf blades, stems and senescent material were oven-dried (at $55{ }^{\circ} \mathrm{C}$, for 48 hours) and weighed for the estimate of the dry matter mass (DM) of the green leaf blade, the stem dry mass, the total biomass, and the proportion of leaf blades to leaf blade plus stem $(\mathrm{L} / \mathrm{L}+\mathrm{S})$. The two fractions and the senescent material were ground using a Wiley mill (1 mm mesh) to determine their percentage of crude protein $(\mathrm{CP}$ : $\mathrm{N} \times 6.25)$ using the semi-micro Kjeldahl procedure (Digestion Unit 2040 and 25 Distillation Unit 1026, Tecator, Högänas, Sweden).

The maximum and minimum air temperatures, recorded in a meteorological shelter $1.50 \mathrm{~m}$ above the ground, were obtained from the Meteorological Station of the Faculty of Agronomy (UNLPam), located $0.5 \mathrm{~km}$ from the experimental site. The thermal sum (degree days; DD) of the growing season (from October 1) was calculated to determine the patterns of biomass accumulation and $\mathrm{CP}$ percentage by the accumulated temperature, using the equation:

$D D=\sum_{i=1}^{n}(T m-T b)$, where if $\mathrm{DD}<\mathrm{Tb}$ then $\mathrm{DD}=\mathrm{Tb}$

where $\mathrm{Tm}$ is the mean daily temperature ((daily maximum temperature + daily minimum temperature $/ 2), \mathrm{Tb}$ is the base temperature $\left(10^{\circ} \mathrm{C}\right)$ and $\mathrm{n}$ is the number of days after October 1.

The data were analyzed using InfoStat (2008). The effect of the growing season on the total accumulation of dry mass, the green leaf blade proportion and the protein percentage of the green leaf blade, stem and senescent material was evaluated using an analysis of variance from the following model: Yijk $=\mu+\alpha \mathrm{i}+\beta \mathrm{j}+\alpha \mathrm{i}$ $* \beta \mathrm{j}+\alpha \mathrm{i}(\delta \mathrm{k})+\varepsilon \mathrm{ijk}$, where $\mu$ is the general mean, $\alpha, \beta$ and $\delta$ are the effects of season, harvest date and repetition, respectively, and $\varepsilon$ is the random error. First, the variation between the repetitions 
within a season ( $\mathrm{dk}(\alpha \mathrm{i}))$ was used as a reference to compare the variation due to the season. The comparisons of differences among the means were evaluated using DGC test (Di Rienzo et al., 2001) $(\alpha=0.05)$. Next, the seasons without differences between them $(\mathrm{P}>0.05)$ were clustered, and linear and quadratic regressions with the thermal sum accumulated from October 1 as the independent variable were fitted for each variable. The quadratic term was included in the model only if its contribution to the relationship was significant $(\mathrm{P} \leq 0.05)$.

\section{Results and discussion}

All of the variables under study differed between the 2003/04 growing season and the other seasons $(P \leq 0.05)$. Hereafter, the $2003 / 04$ season will be referred to as the "dry season", and the others as the "normal seasons".

The total biomass accumulation increased linearly and the proportion of green leaf blade decreased quadratically $(\mathrm{P} \leq 0.01)$ through all of the growing seasons as the DD increased (Table 1; Figure 2) and the plants matured. The rates of biomass accumulation were 0.14 for the dry season and $0.21 \mathrm{~g} \mathrm{DM} \mathrm{m}^{-2} \mathrm{DD}^{-1}$ for the normal seasons. The decrease in the proportion of leaf blade as the DD increased was less noticeable in the dry season than in the normal seasons (Figure 2). These results suggest that the nutritive value of kleingrass would be higher in dry years as, in general, the leaf blade is more digestible than the stems, as demonstrated by Jung and Vogel (1992).

\section{a)}

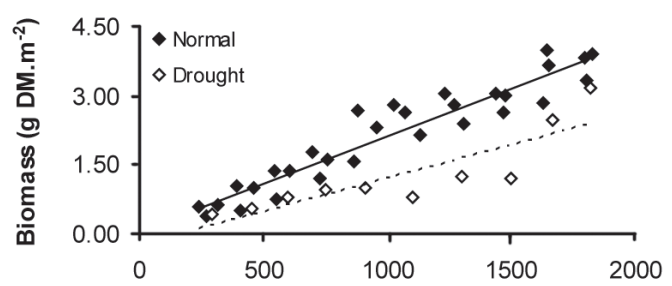

b)

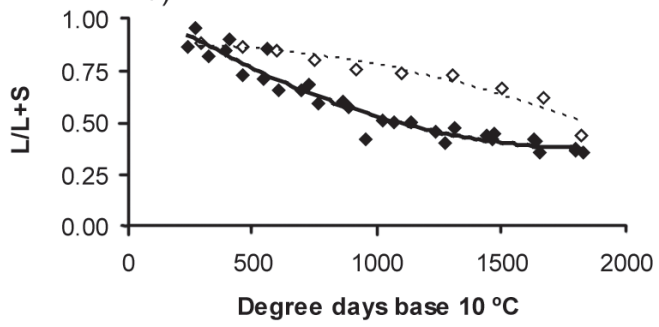

Figure 2. a) Total biomass, and b) green leaf blade proportion (leaf blade/leaf blade+stem; L/L+S), in Panicum coloratum L., cv. Verde, under growing seasons with different quantities of rainfall.

The $\mathrm{CP}$ percentage in the DM of the leaf blade, the stem fractions, the senescent material and the total biomass decreased $(\mathrm{P} \leq 0.05)$ quadratically with increasing DD (Table 2; Figure 3). In addition, the CP percentage was negatively related to increasing biomass accumulation due to $\mathrm{N}$ dilution in the dry matter by the plant growth, as demonstrated by Bélanger et al. (2001) in other species. The

Table 1. The regression equations for the curves in Figure 2, relating the total biomass and the green leaf blade proportion (leaf blade/leaf blade + stem; $\mathrm{L} / \mathrm{L}+\mathrm{S}$ ) in Panicum coloratum, cv. Verde, to the degree days $\left(\mathrm{DD}\right.$; base $10^{\circ} \mathrm{C}$ ) beginning October 1 in growing seasons with different quantities of rainfall.

\begin{tabular}{lcccc}
\hline Variable/Condition & Regression equation & $\mathrm{R}^{2}$ & $\mathrm{P}^{2}$ value & $\mathrm{RMSE}^{1}$ \\
\hline Biomass $\left(\mathrm{g} \mathrm{DM} \mathrm{m}^{-2}\right)$ & & & & \\
Normal & $3.57+0.207 \mathrm{DD}$ & 0.90 & 0.0001 & 35.6 \\
Drought & $-25.81+0.144 \mathrm{DD}$ & 0.74 & 0.0014 & 47.1 \\
$\mathrm{~L} / \mathrm{L}+\mathrm{S}$ & & & & \\
Normal & $1.10-0.00079 \mathrm{DD}+0.0000002 \mathrm{DD} 2$ & 0.93 & 0.0001 & 0.05 \\
Drought & $0.86+0.00005 \mathrm{DD}-0.0000001 \mathrm{DD} 2$ & 0.93 & 0.0001 & 0.04 \\
\hline
\end{tabular}

${ }^{1}$ RMSE: root mean squared error. 
diminished CP percentage in the total biomass with maturity occurred mainly due to the reduction in the proportion of green leaf blade (Figure 2), as the proportion of stem increased.

In the dry season, the $\mathrm{CP}$ percentage in the total biomass was higher $(\mathrm{P} \leq 0.05)$ than in normal seasons (Figure 3), which might be because of the higher leaf blade proportion during the dry season (Figure 2). The leaf blade fraction has a higher percentage of CP than the stem and the senescent material (Figure 3 ). In addition, all of the fractions and the senescent material presented higher percentage of CP during the dry season than in the other seasons (Figure 3). According to several authors, this increase might be associated with delayed foliar ontogeny (Humpreys, 1991; Guenni et al., 2002). The drought might induce acceleration in foliar senescence, while slowing the maturity of the young leaves (Jones, 1988). The prevalence of either effect would be linked to the drought intensity. The results of this study suggest that, in the presence of a moderate drought, where the accumulated biomass allows unrestricted animal intake, the CP percentages would show an improvement in the response per animal.

The moment and the frequency of the grazing defoliation may be fundamental for supplying quality forage and increasing pasture production and persistence; the rapid decrease in the green leaf blade proportion and the CP percentage after the regrowth in the spring would affect the intake levels of the grazing animals (Ferri, 2002). In general, the leaf blades of grasses have a higher nutritive value than the stems, and the voluntary intake of the leaf blades by sheep and cattle is also higher (Minson, 1990). This might be explained by a lower retention time of the particles of the leaves in the rumen when compared with the stems (Poppi et al., 1985). In this study, the plant maturation process, with a subsequent increase in biomass, affected the leaf blade proportion and the nutritive value of kleingrass, which could cause both a depression in animal intake and change in performance animal per unit of intake with increasing the DD or pasture maturity.

Recent studies of forage intake by grazing ruminants show that the instantaneous intake rate de-

Table 2. The regression equations for the curves in Figure 2, relating the crude protein percentage in the dry matter of the leaf blades, stems, senescent material and the total biomass in Panicum coloratum, $\mathrm{cv}$. Verde, to the degree days (DD; base $10{ }^{\circ} \mathrm{C}$ ) beginning October 1 in growing seasons with different quantities of rainfall.

\begin{tabular}{lcccc}
\hline Variable/Condition & Regression equation & $\mathrm{R}^{2}$ & P value & $\mathrm{RMSE}^{1}$ \\
\hline Leaf blade & $15.77-0.015 \mathrm{DD}+0.0000052 \mathrm{DD}^{2}$ & 0.91 & 0,0001 & 0.86 \\
Normal & $18.06-0.017 \mathrm{DD}+0.0000065 \mathrm{DD}^{2}$ & 0.83 & 0,0022 & 1.12 \\
Drought & & & \\
Stem & $10.80-0,011 \mathrm{DD}+0.0000036 \mathrm{DD}^{2}$ & 0.92 & 0,0001 & 0.64 \\
Normal & $11.60-0,009 \mathrm{DD}+0.0000031 \mathrm{DD}^{2}$ & 0.82 & 0,0027 & 0.81 \\
Drought & $16.45-0,021 \mathrm{DD}+0.0000074 \mathrm{DD}^{2}$ & 0.86 & 0,0001 & 1.28 \\
Senescent & $13.74-0,013 \mathrm{DD}+0.0000045 \mathrm{DD}^{2}$ & 0.65 & 0,0255 & 1.70 \\
Normal & $15.77-0,017 \mathrm{DD}+0.0000056 \mathrm{DD}^{2}$ & 0.93 & 0,0001 & 0.85 \\
Drought & $16.74-0,015 \mathrm{DD}+0.0000054 \mathrm{DD}^{2}$ & 0.88 & 0,0005 & 0.97 \\
Biomass & & & \\
Normal & & & \\
Drought & & & \\
\hline
\end{tabular}

${ }^{1} \mathrm{RMSE}$, root mean squared error. 
a)

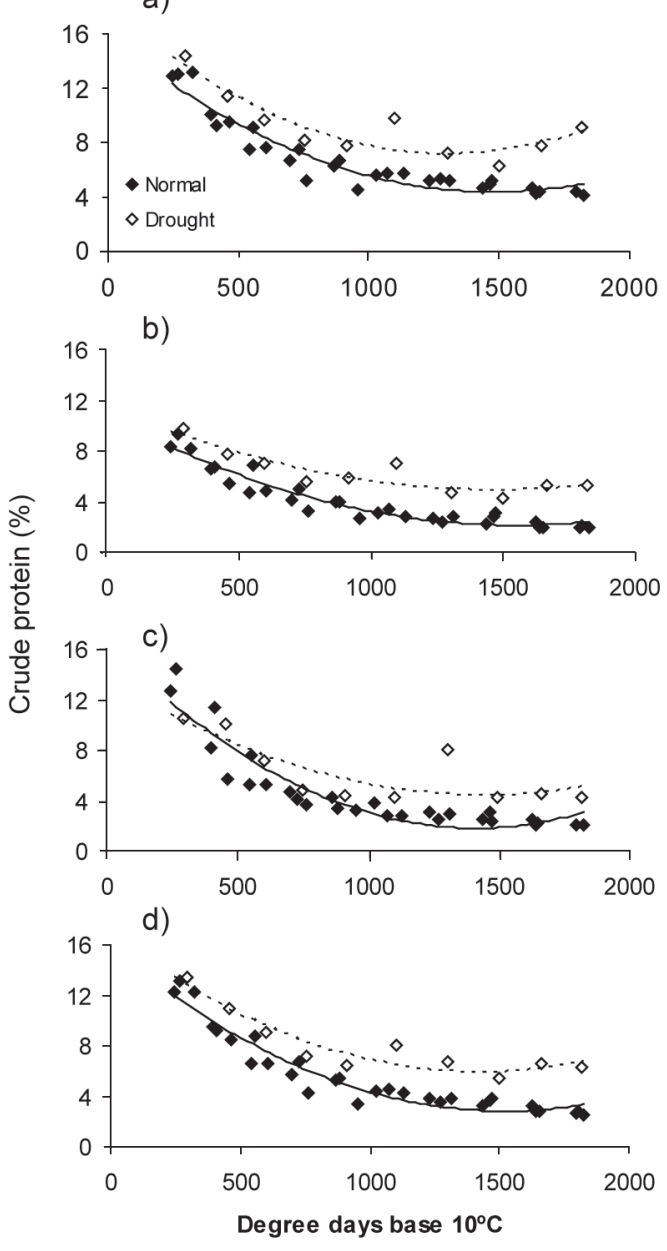

Figure 3. Crude protein percentage in dry matter of a) leaf blade, b) stem, c) senescent material, and d) total biomass, in Panicum coloratum L., cv. Verde, under growing seasons with different quantities of rainfall.

pends on the bulk density and the proportion of morphological fractions with high and low nutritional value (e.g., leaves and stems) in the pasture (Benvenutti et al., 2006; Drescher et al., 2006; Boval et al., 2007; Benvenutti et al., 2008; Van Langevelde et al., 2008). Animals interact with the structure of the pasture by adjusting bite dimensions (e.g., bite area and bite depth) allowing the selection of the more nutritive parts of the sward and increasing the nutritional value of their diets. The pasture maturation process modifies its structure and consequently reduced bites dimensions and affect selectivity. The plant maturation process, in addition to imposing physical restrictions (non nutritional) on the grazing intake, may be restricted by nutritive deficiencies (e.g., protein). In ruminants, levels of crude protein in forage that are lower than $7 \%$ cause a rapid decrease in the intake of dry matter (Minson, 1990).

The results of this study show that a CP percentage of $7 \%$ in the kleingrass DM may be obtained with accumulated biomass of 1.40 or $1.23 \mathrm{Mg} \mathrm{DM} \mathrm{ha}^{-1}$ and a proportion of green leaf blade of 0.67 or 0.81 , in early December or early or mid January, with an accumulation of 660 or 1030 DD, for normal seasons or the dry season, respectively. Several authors have remarked that the maintenance of nutritional quality in the summer is an important feature of kleingrass (Rouquette et al., 1974). Stritzler (2008) observed that the $\mathrm{CP}$ percentage for this species during summer might exceed the percentage for weeping lovegrass by three percent.

The inclusion of kleingrass in the CGS that are usually used in the semiarid Central Pampean region of Argentina, which currently include natural pasture and weeping lovegrass, would improve the seasonal distribution of the available forage, in both quality and quantity, and would therefore be a better fit for the herd demand. Kleingrass would allow cow and calves to attain a better nutritional state and weight during the summer in comparison with those in the systems using only weeping lovegrass and natural pasture.

The increased temperature and the reduced soil humidity forecasted for the coming years in the Southern hemisphere would allow the replacement of $\mathrm{C}_{3}$ pastures with $\mathrm{C}_{4}$ pastures, which have higher optimal temperature for growth and are more tolerant to of drought (Ehleringer et al., 1995). Kleingrass, along with weeping lovegrass, might be among the most used forage resources for diminishing the effects of climate change in the semiarid Central Pampean region.

The results of this study will allow the definition of the optimal grazing sequence for weeping lovegrass and kleingrass in combination with natural pasture in breeding systems in the semiarid Central Pampean region of Argentina. This information should be complemented by grazing trials order to evaluate the pasture production and persistence along with the animal response. 


\section{Resumen}

C.M. Ferri. 2011. Patrones estacionales e interanuales de acumulación de biomasa y proteína bruta en mijo perenne (Panicum coloratum), en la región Pampeana semiárida central de Argentina. Cien. Inv. Agr. 38(2): 191-198. Mijo perenne (Panicum coloratum L. var. coloratum) es una gramínea $\mathrm{C}_{4}$ perenne que inicia su crecimiento en primavera más tarde que el pasto llorón (Eragrostis curvula (Schrad.) Nees). Esto sugiere que la combinación del pasto llorón con el mijo perenne puede incrementar la producción animal. El objetivo de este estudio fue determinar los patrones estacionales e interanuales de acumulación de materia seca (MS) y de porcentaje de proteína bruta (PB) en P. coloratum, cv. Verde, en la región Pampeana semiárida central de Argentina. El estudio se realizó durante cuatro temporadas de crecimiento en una pastura de mijo perenne de 3,0 ha, implantada en la primavera de 1996. Se tomaron muestras de forraje, cada dos semanas, las que fueron separadas en láminas, tallos (incluyendo vaina e inflorescencia) y material senescente. Finalmente, se evaluaron los patrones de acumulación de materia seca y porcentaje de proteína bruta con relación al tiempo térmico acumulado desde el inicio de Octubre y hasta fines de Febrero. En comparación con las otras temporadas de crecimiento evaluadas, la tercer temporada de crecimiento, presento una menor $(\mathrm{P} \leq 0,01)$ acumulación de materia seca y una mayor $(\mathrm{P} \leq 0,01)$ proporción de lámina verde y PB. La acumulación de MS incrementó, mientras que, la proporción de lámina verde y el porcentaje de PB en la biomasa total y en todas las fracciones consideradas decrecieron con el tiempo térmico. La disminución del porcentaje de PB con el tiempo térmico se correspondió con una reducción en la proporción de lámina verde y en el porcentaje de PB en cada fracción de la planta. Las decisiones de manejo dependen de la evaluación de los cambios en la estructura y el valor nutritivo de la pastura durante la estación de crecimiento. La presente información permitirá ajustar el momento y la secuencia del pastoreo de gramíneas $\mathrm{C}_{4}$ perennes.

Palabras clave: Argentina, biomasa total, lámina foliar, precipitación estacional, región Pampeana semiárida, variación térmica diaria.

\section{References}

Bélanger, G., R. Michaud, P.G. Jefferson, G.F. Tremblay, and A. Brégard. 2001. Improving the nutritive value of timothy through management and breeding. Canadian Journal Plant Science 81:577-585.

Benvennutti, M.A., I.J. Gordon, and D.P. Poppi. 2006. The effect of the density and physical properties of grass stems on the foraging behaviour and instantaneous intake rate by cattle grazing an artificial reproductive tropical sward. Grass and Forage Science 61:272-281.

Benvennutti, M.A., I.J. Gordon, D.P. Poppi, R. Crowther, and W. Spinks. 2008. Foraging mechanics and their outcomes for cattle grazing reproductive tropical swards. Applied Animal Behaviour Science 103:15-31.

Boval, M., A. Fanchone, H. Archimède, and M.J. Gibb. 2007. Effect of structure of a tropical pasture on ingestive behaviour, digestibility of diet and daily intake by grazing cattle. Grass and Forage Science 62:44.54.

Cano E. 1980. Inventario integrado de los recursos naturales de la provincia de La Pampa. INTA, Provincia de La Pampa, UNLPam. 493 pp.

Di Rienzo, J.A., A.W. Guzmán, and F. Casanoves. 2002. A multiple comparisons method based on the distribution of the root node distance of a binary tree. Journal of the Agricultural, Biological and Environment Statistics 7:1-14.

Drescher, M., I.M.A. Heitköning, J.G. Raats, and H.H.T. Prins. 2006. The role of grass stems as structural foraging deterrents and their effects on the foraging behaviour of cattle. Applied Animal Behaviour Science 101:10-26.

Ehleringer J.R., Cerling T.E. and Helliker B.R. 1997. $\mathrm{C}_{4}$ photosynthesis, atmospheric $\mathrm{CO}_{2}$, and climate. Oecologia 112:285-299.

Ferri, C.M. 2002. Implicancias del diferimiento de la utilización de Panicum coloratum L. sobre 
la estructura de la vegetación, la composición química del forraje y el consumo de ovinos en pastoreo. Tesis Doctoral. Facultad de Ciencias Agrarias, Universidad de Mar del Plata, Mar del Plata, Argentina. 161 pp.

Ferri, C.M., M.A. Brizuela, M.S. Cid, and N.P. Stritzler 2006. Dinámica de acumulación de láminas foliares y estructura del forraje diferido de Panicum coloratum L. Agricultura Técnica (Chile) 66:376-384.

Ferri, C.M., H.J. Petruzzi, N.P. Stritzler, and V.V. Jouve. 1998. Consumo voluntario, digestibilidad in vivo y proteína bruta dietaria en distintas épocas de utilización de Panicum coloratum diferido. Revista Argentina Producción Animal 18:163-170.

Gargano, A.O., M.A. Adúriz, H.M. Arelovich, and M.I. Amela. 2001. Forage yield and nutritive value of Eragrostis curvula and Digitaria eriantha in central-south semi-arid Argentine. Tropical Grassland 35:161-167.

Gillen, R.L., W.A Berg., CH.L. Dewald, and P.L. Sims 1999. Sequence grazing systems on the souerthen plains. Journal Range Management 52:583-589.

Gillen, R.L., and W.A. Berg. 2001. Complementary grazing of native pasture and old world bluestem. Journal Range Management 54:348-355.

Guenni, O., D. Martín, and Z. Baruch. 2002. Responses to drought of five Brachiaria species. I. Biomass production, leaf growth, root distribution, water use and forage quality. Plant and Soil 243:229-241.

Humphreys, L.R. 1991. Tropical pasture utilization. Cambridge University Press, Cambridge, UK, $206 \mathrm{pp}$.

InfoStat. 2008. InfoStat versión 2008. Grupo InfoStat, FCA, Universidad Nacional de Córdoba, Argentina.

IPCC (Intergovernmental Panel on Climate Change). 2007. Climate change 2007: The physical science basis. Contribution of working group I to the fourth assessment report of the intergovernmental panel on climate change. Cambridge University Press, Cambridge, UK, 996 pp.

Jones, M.B. 1988. Water relations. In: M.B Jones and A. Lazenby (eds). The grass crop. The physiological basis of production. Chapman and Hall Ltd. New York, USA. p. 205-242.

Jung, H.G, and K.P. Vogel. 1992. Lignification of switchgrass (Panicum virgatum) and big blue- stem (Andropogon gerardii) plant parts during maturation and its effect on fiber degradability. Journal Science Food Agricultural 59:169-176.

Minson, D.J. 1990. Forage in ruminant nutrition. Academia Press Inc., San Diego, CA., USA. 483 pp.

Moore, K.J., T.A. White, R.L. Hintz, P.K. Patrick, and E.C. Brummer. 2004. Sequential grazing of cool- and warm-season pastures. Agronomy Journal 96:1103-1111.

Nazar Anchorena, J.B. 1988. Pastizales naturales de La Pampa. Convenio AACREA - provincia de La Pampa, Argentina. 112 pp.

Petruzzi, H.J., N.P.Stritzler, E.O. Adema, C.M. Ferri, and J.H. Pagella. 2003. Mijo perenne. 10 Publicación Técnica No 51. INTA, EEA Anguil "Ing. Agr. G. Covas.”, La Pampa, Argentina. 28 pp.

Podestá G.P., C.D. Messina, M.O. Grondona, and G.O. Magrin 1999. Associations between grain crop yields in central-eastern Argentina band El Niño-Southern Oscillation. Journal of Applied Meteorology 38:1488-1498.

Poppi, D.P., R.E. Hendricksen, and D.J. Minson 1985. The relative resistence to escape of leaf and stem particles from the rumen of cattle and sheep. Journal of Agricultural Science 105:9-14.

Rouquette, F.M., E.C. Holt, and W.C. Ellis. 1974. Nutritive characteristics of kleingrass at various stages of maturity. I. Chemical evaluations of experimental synthetic varieties. Agronomy Journal 66:506-510.

SAyDS (Secretaria de Ambiente y Desarrollo Sustentable). 2006. Primer inventario nacional de bosques nativos. Inventario de campo de la región del espinal distritos caldén y ñandubay. Anexo 1. Estado de conservación del distrito caldén. $77 \mathrm{pp}$.

Stritzler, N.P., J.H. Pagella, V.V. Jouve, and C.M. Ferri. 1996. Semi-arid warm season grass yield and nutritive value in Argentina. Journal Range Management 49:121-125.

Stritzler, N.P. 2008. Producción y calidad nutritiva de especies forrajeras megatérmicas. Revista Argentina de Producción Animal 28:165-168.

Van Langevelde, F., M. Drescher, I.M.A. Heiköning, and H.H.T. Prins. 2008. Instantaneous intake rate of herbivores as function of forage quality and mass: Effects on facilitative and competitive interactions. Ecological Modelling 213:273-284.

Yahdjian L. and Sala O.E. 2008. Climate change impacts on South American Rangelands. Rangelands 30:34-39. 